\title{
On the Impact of Geometry Scaling and Mass Flow Rate on the Frequency of a Sweeping Jet Actuator
}

Ph D. Candidate Khalifa University Department of Aerospace Engineering

This paper presents an experimental and numerical study of the sweeping jet oscillation frequency which is a crucial parameter for effective separation control. Measurements of the time-resolved static pressure are made in the feedback channels using high-frequency pressure transducers. Experiments are performed for eight different inlet mass flow rates (from $1 \mathrm{~g} / \mathrm{s}$ to $8 \mathrm{~g} / \mathrm{s}$ ). The effects of geometry scaling are examined for the halfand double-size of the baseline actuator. The results reveal a relationship between the oscillating frequency and the inlet mass flow rate and demonstrate a linear trend of the Strouhal number versus the inlet Mach number for all the geometries. The experimental results are compared toresults obtained from numerical simulations using Ansys Fluent v17.2 software.A high correspondence is found between experimental results and numerical data from computationally inexpensive $2 D$-URANS simulations. This result opens possibilities of using these simple numerical models to perform extensive studies of the geometric parameters of the sweeping jet actuator in the future.

Keywords: Active Flow Control, Sweeping Jet Actuator, Internal Flows, Computational Fluid Dynamics, Unsteady Pressure

\section{INTRODUCTION}

Flow control plays a distinctive role in developing the future generation of aircraft and technologies [1], which are expected to have progressivelyimproved flight performance and efficiency. Given that the passenger traffic is increasing exponentially in recent years [2], some of theprimary concerns for today's civil aviation are an improved fuel economy and a reduced ecological footprint, if this growth is to be sustainable. Many types of passive devices, such as winglets [3] or vortex generators [4], are used to improve the aerodynamic performance and reduce power requirements. However, these devices are usually fixed and impose certain limitations such as added drag or the inability to adapt to real-time flow conditions. In such cases, active flow control has an increasing potential to bring a range of benefitsin terms of airframe weight reduction, lift increase, drag, and noise reductions, and has become an essential component in aircraft design [5]. In addition to aerodynamic improvements, active flow control is increasingly interesting in a myriad of other applications, such as: control of boundary layers in wind tunnels[6], smoke propagation [7], flows around hydrodynamic surfaces [8], noise reduction [9], flows around miniature UAVs [10-12], separated flows in supersonic nozzles [13], or thrust vectoring [14], just to name a few.

Many types of active flow control devices have been

Received: November 2018, Accepted: March 2019 Correspondence to: Vladimir B. Parezanović, Assistant Professor, Khalifa University, Department of Aerospace Engineering, P O Box 127788, Abu Dhabi, UAE

E-mail: vladimir.parezanovic@ku.ac.ae

doi: $10.5937 /$ fmet1903599S

(C) Faculty of Mechanical Engineering, Belgrade. All rights reserved proposed and tested in various fundamental and applied flow problems, as summarized in the seminal review paper of Cattafesta and Sheplak [15]. One of the most common actuator groups are the fluidic oscillators: devices that produce a continuous oscillating jet when supplied with a pressurized fluid [16]. The Coanda effect $[17,18]$ is one of the main operating principles of these actuators. The type investigated in this paper is a fluidic oscillator using two feedback channels, called the Sweeping Jet (SWJ) actuator. The usual configuration of the SWJ actuator contains no moving parts which is one of the main advantages. Other advantages of SWJ actuators are the variety of size and frequencies, self-governing control of frequency, and the ability to produce a disturbance over a large area [19]. On the other hand, the main disadvantage of these devices is that they require an external flow source.

The main geometric features of the SWJ type of interest in this study are shown in Figure 1. The actuatoris pressurized at the inlet,and the flow passes through the main chamber at high velocity. The jet attaches to one of the antisymmetric Coanda surfaces. Part of theattached flow enters the feedback channel inlet downstream of the coanda surface in question. The momentum of this reversed flow pushes the attached jet away from the coanda surface and starts to fill the space above the surface, creating a recirculation bubble. As this recirculation bubble grows due to the feedback flow, the jet is progressively pushed away and towards the opposite coanda surface, where it will eventually reattach, and the cycle begins anew [20,21]. This process creates a bi-modal jet which is ejected through the nozzle in a sweeping motion with a well-defined frequency. The sweeping frequency and deflection amplitude are 
determined by many geometric parameters of the actuator cavity as well as the mass flow rate, or rather the pressure levels at the inlet $[20,22,23]$.

Sweeping jet actuators have already been tested in many crucial fundamental flow problems, such as the boundary layer control [24], flow separation [25-28] and combustion control [29]. Recently, the principal aerospace application of the SWJ actuator is in the flow separation control on the vertical tail of an aircraft [3032]. The current study of NASA Langley Research Center shows the efficiency of the SWJ actuators located in the vertical tail over a Boeing 757 ecoDemostrator [33]. The concluding comments of this study state that there is an important enhancement in the side force when the control is active, which produces a vital flow attachment on the vertical rudder. This improves the efficiency of the rudder [34, 35], so its size and mass can be reduced. This is an important result since the rudder imposes drag and weight penalties in all flight regimes, yet its use is crucial only in a very limited range of airspeeds, in regimes such as take-off and landing.

While the fundamental principles of how the SWJ operates are well understood, there remain a number of open questions on both the internal and external flow mechanisms. Only very recently have the properties of the external flow and the jet interaction with the surrounding environment been studied in detail. Numerical and experimental studies of the sweeping jet in crossflow [36] and quiescent environments [37-39] have shed crucial light in understanding and predicting the control authority and impact of the SWJ, applicable to various fundamental flow control problems.

The internal dynamics of SWJs have also been of interest lately. Woszidlo et al. [21] studied the internal flow of the SWJ actuator (Type I) using a high-speed Particle Image Velocimetry (PIV) technology and employing 55 pressure taps dispersed inside the actuator. This study investigated the internal dynamics and elaborated on the recirculation bubble mechanism which is responsible for the jet oscillation. The relationship between the mass flow rate and the jet oscillation frequency has been studied infor several configurations of mass flow rates and working fluids.

Vatsa et al. [40] examines the SWJ actuator numerically, using lattice Boltzmann CFD solvers and compare two different SWJ geometries, Type I (90D actuator) and Type II (curved-wall actuator). A study by Aram et al. [41] examines the SWJ actuator using 2-D URANS, 3-D URANS and 3-D IDDES of the SWJ actuator Type II. In this study, the 3-D IDDES model provided the most accurate results along of the three different models used. Seo et al. [23] use the Immersed Boundary Method (IBM) method of solving the incompressible Navier -Stokes equations to study various geometric parameters and their effects on the internal flow and the output frequency. A simple and elegant phenomenological model is constructed relating the jet deflection and the feedback channel geometry.

The present paper focuses on the experimental and numerical results on the dependence of the SWJ natural oscillation frequency, with respect to the change in scale of the actuatorand the variations of the inlet mass flow rate. The numerical results are obtained using Ansys Fluent v17.2 commercial software package. The internal flow is simulated using 2D-URANS and the SST k- $\omega$ turbulence model. Numerical results are compared with the experimentally obtained time-resolved static pressure measurements from Kulite pressure transducers at key locations. We demonstrate that the SWJ oscillation frequency can be very accurately estimated from computationally inexpensive 2D simulations, which makes future studies of geometric parameters feasible. Our study also elaborates on the relationships between the Strouhal number of the jet and the mass flow rate and the inlet Mach number for the type II SWJ geometry configuration.

\section{METHODOLOGY}

In this section, we present the experimental and numerical setups used to obtain the sweeping jet oscillation frequency with respect to three different scales of the actuator dimensions and various inlet mass flow rates.

The geometry of the actuator, common to both studies, is a Type II curved surface actuator with two feedback channels as patented by Stouffer and Bower [42]. The exit jet nozzle height of the actuator $h=6.35 \mathrm{~mm}$ (see Figure 1.) is the characteristic length, used to define the non-dimensional values of the other geometric parameters. Actuator depth $\mathrm{d}$ is in all cases defined as $\mathrm{d} / \mathrm{h}=1$. Two scaled geometries are also tested; a double size $\left(\mathrm{h}_{2.0}=12.70 \mathrm{~mm}\right)$ and a half size $\left(\mathrm{h}_{0.5}=3.175 \mathrm{~mm}\right)$, with respect to the baseline actuator.

The working fluid in both studies is air, and the actuator is expelling the jet into a quiescent environment which is defined as the standard atmosphere at sea level conditions. At the inlet, eight different mass flow rates $\dot{\mathrm{m}}$ of air are considered, from $1 \mathrm{~g} / \mathrm{s}$ to $8 \mathrm{~g} / \mathrm{s}$.

The Strouhal number of the jet oscillations is defined using the nozzle height $\mathrm{h}$, the detected frequency of the jet $\mathrm{f}$, and the inlet velocity $\mathrm{V}_{\mathrm{i}}$ as $S t=\frac{f \cdot h}{v_{i}}$. The Mach number is defined as $\mathrm{M}=\mathrm{V}_{\mathrm{i}} / \mathrm{c}$, where $\mathrm{c}$ is the speed of sound at sea level conditions of the standard atmosphere.

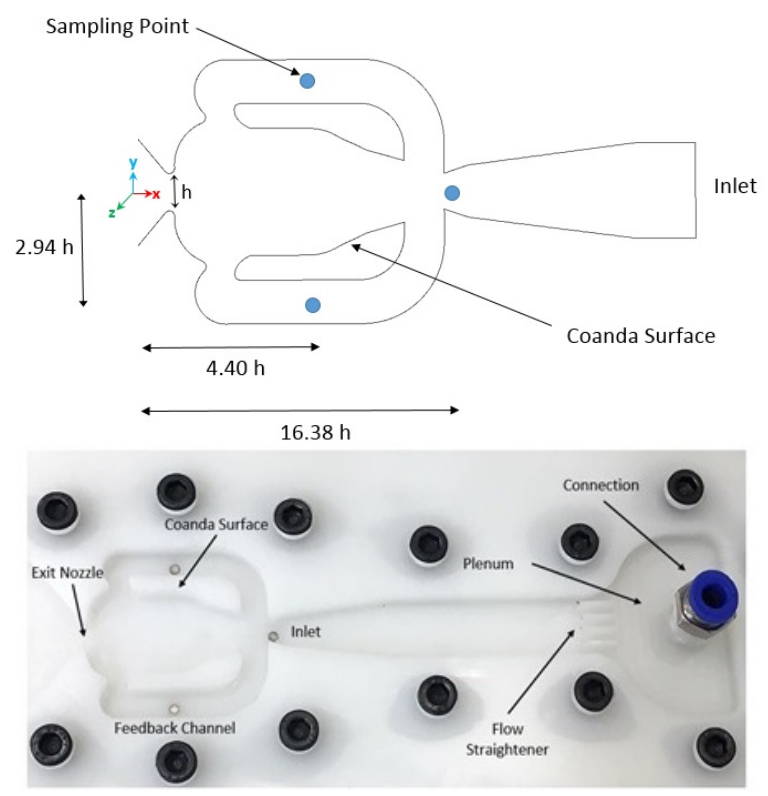

Figure 1. The SWJ Type-II actuator: sketch (above) of the geometry and (below) the manufactured actuator used in the experimental study. 


\subsection{Experimental Setup}

The SWJ actuator's main body with the oscillator cavity has been manufactured out of plastic-nylon,through a milling process. A plexyglass (PMMA) cover is then bolted onto the actuator cavity. A pressure inlet tube connector is located on the cover above the plenum chamber (see Figure 1.). The same layout and manufacturing process is used for all three actuator scales.

In order to measure the frequencies of the internal flow, three static pressure ports have been provided; one in each feedback channel and one at the inlet, as illustrated in Figure 1. Time-resolved dynamics of the static pressure are captured at these locations, using Kulite XTL-140 high-frequency absolute pressure transducers. The transducers have a maximum sampling frequency of $50 \mathrm{kHz}$, with a very high sensitivity to pressure differentials. The excitation voltage for the transducer is $10 \mathrm{~V}$, the pressure range is up to $1.7 \mathrm{bar}$, with a maximum operating pressure of 1.4 bar. The pressure transducers are connected to a signal conditioner, model KSC2, which amplifies the signal and provides the mentioned excitation voltage. This signal conditioner is connected to a data acquisition system (NI cDAQ ${ }^{\mathrm{TM}}-917$ ), which is used to sample and record the static pressure time series.

The pressurized airat the connection to the plenum chamber is provided by a 7-bar compressed air source. The mass flow rate is controlled by an ALICAT MCR1500SLPM mass flow meter. The mass flow meter is controlled electronically, and it is used to set the desired mass flow rate. The total pressure is measured by introducing a miniature Pitot tube $(\Phi=1 \mathrm{~mm})$, through the exit nozzle up to the inlet. The Pitot tube is connected to an electronic manometer COMARK C9555 which has a resolution of $10 \mathrm{~Pa}$ and an accuracy of \pm $420 \mathrm{~Pa}$, over the operational range of $\pm 210 \mathrm{kPa}$. Mean static pressure from the inlet Kulite sensor and the total pressure from the Pitot tube are then used to calculate the inlet velocity, assuming incompressible flow conditions. The time-resolved static pressure signals in feedback channelsaretypically acquired with a sampling rate of $\mathrm{f}_{\mathrm{a} \text { exp }}=10 \mathrm{kHz}$, during a $\mathrm{T}_{\mathrm{a} \text {,exp }}=1 \mathrm{~s}$ acquisition period, yielding an $\mathrm{n}_{\mathrm{s}, \exp }=10000$ samples. The signals are normalized by the mean value of the signal $\left(\mathrm{P} / \mathrm{P}_{\text {mean }}\right)$. The signals are compared using the dimensionless time $\mathrm{t}^{*}$, which is defined as the duration of ten full oscillation periods. Since the inlet velocity is measured by intrusive means, the blockage ratio (BR) between the Pitot tube area and the inlet area must be considered. The BR values are: $8 \%$ for the original geometry, $32.5 \%$ for the $\mathrm{h}_{0.5}$ geometry, and $2 \%$ for the $\mathrm{h}_{2.0}$ geometry. The estimation of the inlet velocity for the half-size geometry is inaccurate and unreliable, due to a high blockage ration, and is not presented.

\subsection{Numerical Setup}

The computational fluid dynamics software Ansys Fluent v17.2 is used to solve the governing equations for conservation of mass and momentum. The flow is assumed to be fully turbulent and compressible. The external domain past the jet exit nozzle is semicircular.
The details on the actuator geometry and the computational domain definition are given by Kara [43]. Computational meshes havebeen created by the Ansys Meshing software, and a detailed mesh study is performed to optimize the accuracy of the results, as described in [44].

The simulations used Two-Dimensional Unsteady Reynolds Averaged Navier-Stokes equations (2DURANS) and Menter's Shear Stress Transport (SST) k- $\omega$ turbulence model [45]. The boundary conditions for all the wall surfaces are defined as no-slip, no-penetration, and adiabatic. The pressure outlet is assumed to open to the ambient environment with $\mathrm{p}_{\infty}=101,325 \mathrm{~Pa}$ and $\mathrm{T}_{\infty}=$ $298.16 \mathrm{~K}$. The computational domainhas pressure gradient, which creates a continuous flow in the streamwise direction $(+x)$. The mass flow rate is defined as the mass flux through the inlet boundary (two dimensional).

Each simulation is performed for 5,000 steps without data sampling, and after with data sampling for 100,000 steps. The time step is constant and equal to $\mathrm{dt}$ $=10^{-5}$ seconds, and the total sampled time is $\mathrm{T}_{\mathrm{a}, \mathrm{CFD}}=1 \mathrm{~s}$, yielding $\mathrm{n}_{\mathrm{s}, \mathrm{CFD}}=100000$ samples. The static pressure and the velocity are sampled at identical locations as in the experiment (see Figure 1.). Contrary to the experiments, the inlet velocity can be sampled directly and is available for all configurations.

\section{RESULTS AND DISCUSSION}

In this section, we will present the experimental and numerical resultsof the static pressure fluctuations in the feedback channel. These measurements yield the frequency of the oscillating jet and are obtained for eight different mass flow rates, from $1 \mathrm{~g} / \mathrm{s}$ to $8 \mathrm{~g} / \mathrm{s}$. In addition to that, two scaled geometries (half- and double-size) of the actuator are tested in addition to the baseline geometry. The relationship between the mass flow rate and the frequency for all cases is discussed.

\subsection{Baseline geometry pressure fluctuations}

The time series of normalized static pressure $\mathrm{P} / \mathrm{P}_{\text {mean }}$ from experimental and numerical studies are plotted versusthe non-dimensional time $t^{*}$ in Figure 2. These results are obtained for the baseline geometry and mass flow rates of $1 \mathrm{~g} / \mathrm{s}, 4 \mathrm{~g} / \mathrm{s}$, and $7 \mathrm{~g} / \mathrm{s}$. We can conclude that the numerical data fits well, in a qualitative sense, with the experimental counterparts. An exception is the case of the very low $1 \mathrm{~g} / \mathrm{s}$ mass flow rate, where the numerical solution shows a presence of additional noise in the higher frequency bands. This could be an artifact of the numerical model since the experimental data shows no similar tendency. In all three cases, however, the amplitude of pressure oscillations is higher for the numerical solution than in the corresponding experiment.

In order to analyze quantitatively and compare the pressure signals from the two studies, the Fast Fourier Transform (FFT) of the normalized pressure $\mathrm{P} / \mathrm{P}_{\text {mean }}$ has been performed for the mentioned mass flow rates, and the resulting Power Spectral Density (PSD) spectra are shown in Figure 3. Based on the signal acquisition settings for the experiment and the computation model in the numerical study, the spectra in both cases have a frequency resolution of $\mathrm{df}=1 \mathrm{~Hz}$. The spectra confirm 
an overestimation of the fluctuation amplitude in the numerical case, however, we find that the temporal dynamics, reflected in the base frequencies, are in very good correspondence between the two studies. The base frequency peaks are well defined in all cases, which is an expected result for this class of fluidic oscillators, where the natural frequency is very well defined [46].
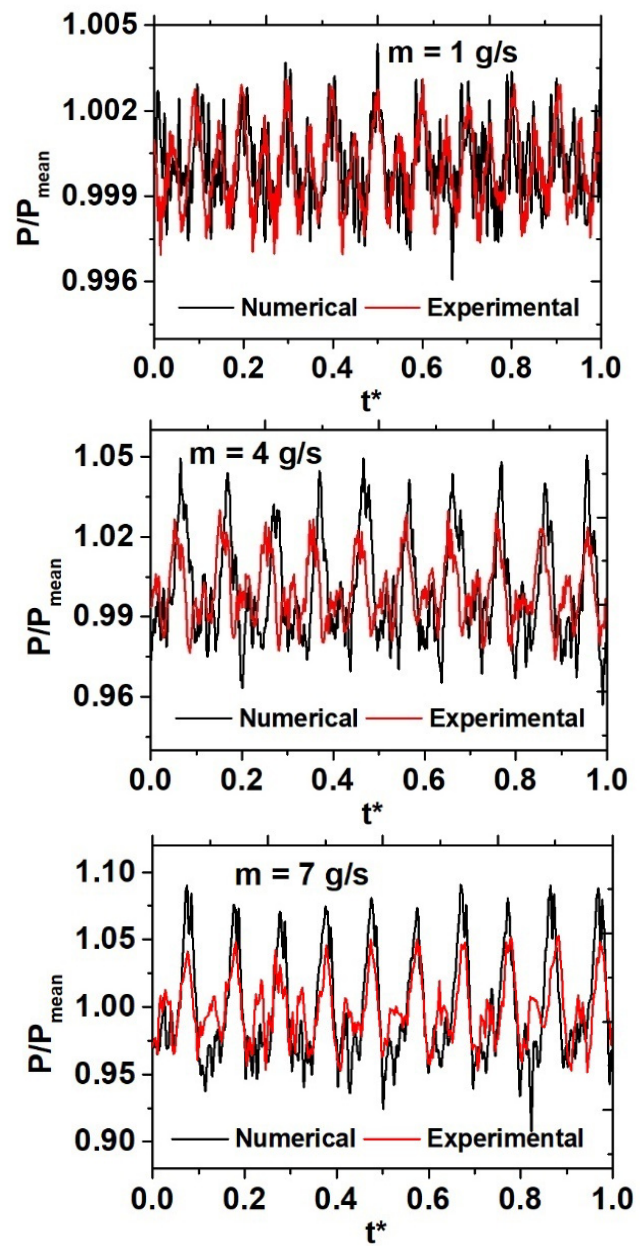

Figure 2. The time series of the static pressure in the feedback channel, normalized by its mean value and plotted vs. dimensionless time $\mathbf{t}^{*}$ for $\dot{m}=\mathbf{~ g} / \mathrm{s}, 4 \mathrm{~g} / \mathrm{s}$, and $7 \mathrm{~g} / \mathrm{s}$.

The resulting base frequency for each mass flow rate testedis displayed in Table 1 . for both experimental $f_{\exp }$ and numerical $\mathrm{f}_{\mathrm{CFD}}$ studies. Additionally, the Strouhal and the Mach numbers have been calculated for each case. In the case of the baseline geometry, the Strouhal number has a small range of values between 0.015 0.019 with an average value of $\mathrm{St} \approx 0.017$.

The values of the Mach number, estimated in the experiment using the miniature Pitot tube, range from 0.057 to 0.467 . This indicates that the flow is mostly in the incompressible regime for the tested mass flow rates and the baseline geometry. However, the disagreement between the Mach number in the experiment and the CFD starts to appear for $\dot{\mathrm{m}}=6 \mathrm{~g} / \mathrm{s}$ and $\dot{\mathrm{m}}=8 \mathrm{~g} / \mathrm{s}$. This could be due to inaccuracy in the Pitot tube measurements since the two data points deviate in different directions. This deviation is apparent in the Strouhal number, as it is a function of the inlet velocity.

We can conclude that all values presented increase as the mass flow rate increases, and this relationship will be described and discussed in the following sections.
Table 1. Comparison between experimental and numerical jet oscillation frequency for the baseline actuator.

\begin{tabular}{|c|c|c|c|c|c|c|c|}
\hline \multicolumn{7}{|c|}{ Baseline Geometry (h = 6.35 mm) } \\
\hline $\begin{array}{c}\dot{\mathrm{m}} \\
\mathbf{( g / \mathbf { s }})\end{array}$ & $\mathbf{M}_{\exp }$ & $\begin{array}{c}\mathbf{f}_{\text {exp }} \\
\mathbf{( H z )}\end{array}$ & $\mathbf{S t}_{\exp }$ & $\mathbf{M}_{\text {CFD }}$ & $\begin{array}{c}\mathbf{f}_{\text {CFD }} \\
\mathbf{( H z )}\end{array}$ & $\mathbf{S t}_{\mathbf{C F D}}$ & $\begin{array}{c}\Delta \mathbf{\Delta} \\
\mathbf{( \% )}\end{array}$ \\
\hline 1 & 0.057 & 60 & 0.019 & 0.064 & 58 & 0.017 & 3.33 \\
\hline 2 & 0.119 & 115 & 0.017 & 0.127 & 116 & 0.017 & 0.87 \\
\hline 3 & 0.191 & 167 & 0.016 & 0.185 & 174 & 0.017 & 4.19 \\
\hline 4 & 0.251 & 215 & 0.015 & 0.243 & 225 & 0.017 & 4.65 \\
\hline 5 & 0.286 & 261 & 0.016 & 0.280 & 274 & 0.018 & 4.98 \\
\hline 6 & 0.303 & 303 & 0.018 & 0.369 & 318 & 0.016 & 4.95 \\
\hline 7 & 0.375 & 346 & 0.016 & 0.396 & 351 & 0.016 & 1.45 \\
\hline 8 & 0.467 & 386 & 0.015 & 0.419 & 377 & 0.016 & 2.33 \\
\hline
\end{tabular}
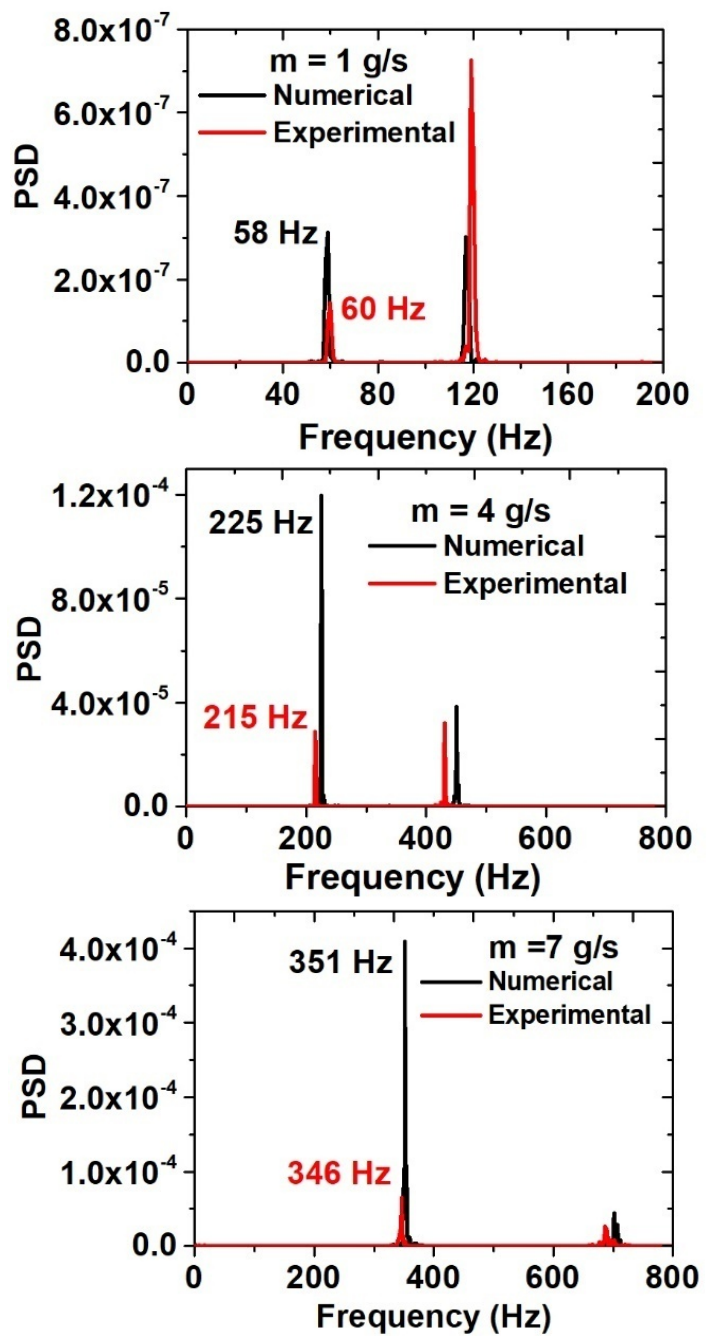

Figure 3. Power Spectral density (PSD) of the normalized static pressure for $\dot{m}=1 \mathrm{~g} / \mathrm{s}, 4 \mathrm{~g} / \mathrm{s}$, and $7 \mathrm{~g} / \mathrm{s}$. Base frequencies are indicated for each case.

\subsection{Half-size and double-size geometries}

As stated previously, two additional sizes of the baseline geometry are tested. The objective is to assess the impact of the actuator scale on the output frequency. This is an important aspect for flow control, as the potential practical applications of these actuators might imply very different scales.

The small dimensions of the half-size actuator impose considerable limitations on the pressure imposed at the inlet. In this case, the operating limits of the pressure transducers of 1.4 bar are achieved for a mass flow rate of $3 \mathrm{~g} / \mathrm{s}$. We have, therefore, limited the mass 
flow rates for the half size geometry to a range from $0.25 \mathrm{~g} / \mathrm{s}$ to $2.5 \mathrm{~g} / \mathrm{s}$. However, the double-size actuator has been studied with the same mass flow rates as the baseline geometry, from $1 \mathrm{~g} / \mathrm{s}$ to $8 \mathrm{~g} / \mathrm{s}$ with an increment of $1 \mathrm{~g} / \mathrm{s}$. The resulting detected frequencies for both geometries, with respect to the appropriate mass flow rates,are shown in Table 2.

Table 2. Experimental and numerical results of the jet oscillation frequencies for the half- and double-size geometries.

\begin{tabular}{|c|c|c|c|}
\hline \multicolumn{5}{|c|}{ Half-size geometry $\mathbf{( h}_{\mathbf{0 . 5}}=\mathbf{3 . 1 7 5}$} \\
$\mathbf{m m})$
\end{tabular}

We can note that the half-sized geometry produces jet oscillation frequencies in a very high-end range from 163 $\mathrm{Hz}$ to $804 \mathrm{~Hz}$, even with the much smaller mass flow rates. The double-sized geometry, employed in the same mass flow rate range as the baseline, produces jet oscillation frequencies in a very low-end range from $7 \mathrm{~Hz}$ to $53 \mathrm{~Hz}$. These experimentally obtained results are mostly in good agreement with their numerical counterparts, with a few exceptions. We can conclude that the geometry scaling plays a large part in the determination of the jet oscillation frequencies for a fixed range of mass flow rates.

\subsection{Mass flow rate vs. frequency}

The summary of the experimental and computational results for all three geometries is shown in Figure 4., where the oscillation frequency is plotted with respect to the mass flow rates. In addition to the current results, we have included other computational and experimental data obtainable from the previous studies [40, 43], which emphasize a good overall agreement with the current study for the baseline geometry.

The data indicates a near linear distribution of oscillating frequencies with different slopes for each geometry scale. Of note is a slight tendency of slope change for the higher end of the half-size geometry curve, for both experimental and numerical data. However, the two affected data points are not enough to make a conclusive remark on whether this might be an initial effect of compressibility.

Figure 5. depicts the numerical and experimental Strouhal numbers versus the inlet Mach number for all cases where it was possible to accurately estimate the latter. It can be concluded that the Strouhal number is constant with the inlet Mach number and has an average value of $\mathrm{St} \approx 0.017$ across all applicable cases. From the estimated Mach number values, it should be noted that the current study is performed in the incompressible flow range. The compressibility effects can lead to frequency saturation, as described in von Gosen et al. [46]. A linear relationship between the oscillation frequency and the Mach number has been observed [47], but according to Hirsch et al. [48], this may not always be the case.

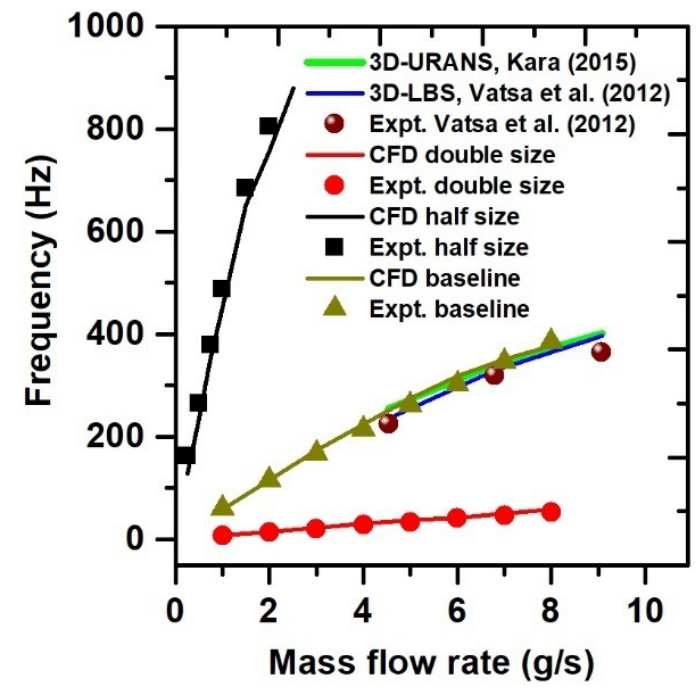

Figure 4. Oscillating frequency vs. mass flow rate for all geometries and comparison between current and results from literature.

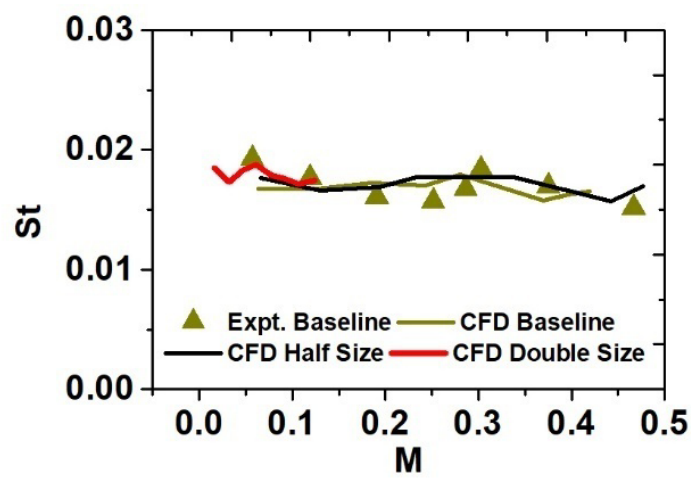

Figure 5. Strouhal number of the oscillating jet vs.the inlet Mach number.

In conclusion, the Strouhal number can be considered as invariable with respect to the inlet Mach number for the different scales of the actuator. This implies that the internal flow dynamics and the actuator output are maintained when the scale of the geometry is modified.

\subsection{Experimental vs. CFD results}

A secondary objective of this study is to validate the use of a 2D URANS simulation model in the estimation of the natural frequency of an SWJ actuator. A more accurate simulation of all aspects of the internal flow dynamics would certainly have to include $3 \mathrm{D}$ effects as noted in [40]. However, the goal in our case is to examine the usefulness of a computationally less expensive 2D model targeted at predicting the oscillation frequency as the key parameter for the use of SWJs in flow 
control. We, will, therefore, comment only on the agreement of the oscillation frequency between the experimental and numerical studies, since a deeper study would be out of the scope of the current paper.

The agreement between the obtained experimental $\left(f_{\text {exp }}\right)$ and computational $\left(f_{\text {CFD }}\right)$ jet oscillation frequency can be represented as: $\Delta f=\left|1-\left(\mathrm{f}_{\mathrm{CFD}} / \mathrm{f}_{\text {exp }}\right)\right| \cdot 100[\%]$. The resulting values of $\Delta \mathrm{f}$ for all three geometries are given in Tables 1 . and 2.

The baseline case demonstrates by far the best agreement between the experiment and the numerical model. The highest discrepancy, in this case, is only $4.98 \%$, with an average discrepancy of $3.345 \%$ across all flow rates. This level of accuracy for the $2 \mathrm{D}$ computational model is very good even whencompared tothe frequency prediction performance of $3 \mathrm{D}$ numerical models in other studies.

However, the same level of agreement is not obtained for the scaled geometries. In the case of the doublesize geometry, the largest discrepancy is $15 \%$, the average $\Delta \mathrm{f}$ across the different mass flow rates being around $10 \%$. The half-size geometry causes a discrepancy of up to $21.48 \%$, with an average $\Delta f$ of $9.48 \%$ across all cases. The reasons for these lower agreements between the experimental and numerical data may come from the difficulties in the experimental setup, rather than the inaccuracy of the computational model.

For example, in the case of the double-size geometry, for $\dot{m}=1 \mathrm{~g} / \mathrm{s}$, the detected frequencies are $\mathrm{f}_{\exp }=$ $7 \mathrm{~Hz}$ and $\mathrm{f}_{\mathrm{CFD}}=8 \mathrm{~Hz}$, giving a difference of only $1 \mathrm{~Hz}$ which is the frequency resolution of the FFT of the pressure signals in both cases. For other mass flow rates, the average frequency difference is around $2.8 \mathrm{~Hz}$, which is an acceptable error, depending on the requirements of the application of the SWJ in specific flow control problems. Since the actuator in our case uses air as a working fluid, a precision of $2-3 \mathrm{~Hz}$ of an oscillating jet employed in open-loop flow control of a lowspeed, turbulent flow would be quite acceptable. This especially stands when we consider that most such flow problems exhibit instabilities whose natural frequency is much more poorly defined due to turbulent noise. In cases such as the control of a separated flow [49] or a planar turbulent mixing layer [50], the flow is susceptible to lock-in on a range of frequencies, thus enabling an effective control. We can conclude that designing an SWJ which would target such instabilities, would be very feasible, with the level of precision of the output frequency prediction by the computation model used in this study.

In the case of the half-sized geometry, the discrepancies are, again, most likely coming from the deficiencies in the experimental setup. The mass flow rate measurement and the manual control valve, used in the experiment to set the desired $\dot{\mathrm{m}}$, is very likely not capable of maintaining such low mass flow rates reliably. The $\Delta \mathrm{f}$ values for all three scales are illustrated in Figure 6., using the error bars associated with the mean frequency obtained from the computational model. We can see that the error in the case of the half-sized geometry is gradually reduced as the mass flow rate is increased to levels used in the baseline geometry experiments. This, however, is not a conclusive argu- ment for the vindication of the CFD model, and further examination of the computational mesh quality will be needed to verify whether the experimental setup is indeed the main source of the discrepancy.

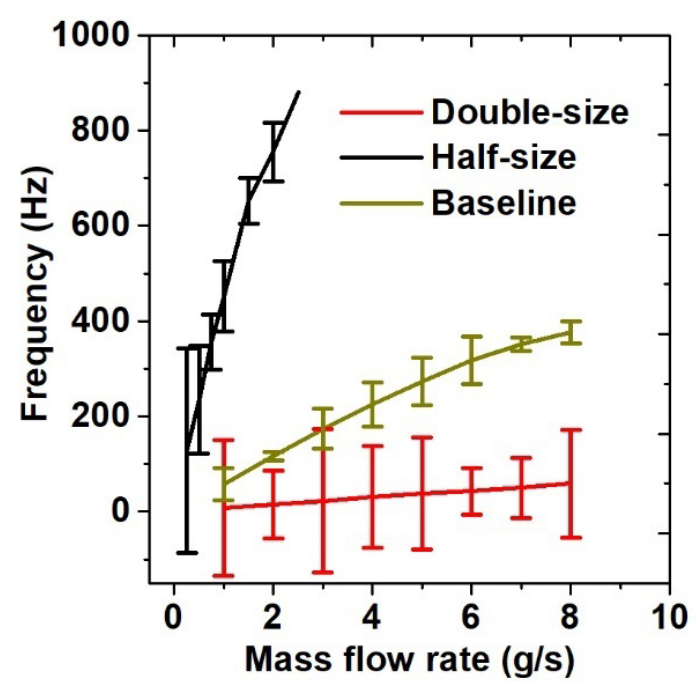

Figure 6. The discrepancy of oscillating jet frequency between the experimental and numerical data for all three geometry scales. Error bars denote $10 \cdot \Delta f(\%)$, where the error percentage is exaggerated for clarity.

\section{CONCLUSIONS}

The present study addresses the impact of the mass flow rate and scale on the natural frequency of the Type II Sweeping Jet Actuator (SWJ). The time-resolved pressure variations in one of the feedback channels, indicative of the jet oscillation frequency, are obtained both experimentally and numerically. The comparison between the two approaches is performed in order to validate the CFD results for a relatively simple and computationally inexpensive 2D URANS, SST k- $\omega$ computational model.Three geometry scales are tested along with eight different mass flow rates, with some exceptions due to experimental setup limits.

A linear dependence is confirmed between the oscillation frequency and the mass flow rate in all three geometry cases. In addition, the Strouhal number is constant with respect to the inlet Mach number in all cases and has an average value of $\mathrm{St} \approx 0.017$. The internal geometry of the SWJ actuator is a crucial constraint for the oscillating frequency, and three different size geometries have been examined in order to understand the scale effect.We can conclude thatthe production of the oscillation inside the SWJ actuator isnot affected by the scaling effect.

Despite difficulties related to the experimental setup as a benchmark and the simplicity of the computational model, the numerical simulation succeeds in giving a very accurate prediction of the oscillatory behavior of the actuator.Theobtained results match the experimental data, within a deviation of less than $5 \%$ in the baseline geometry case. The probable reasons for the higher deviation for other geometry sizes are addressed in the discussion and are mostly attributed to the sub-optimal experimental tools, presently at our disposal. Based on the comparison between current experimental and numerical results with previous studies, we can note that 
the approximation to a $2 \mathrm{D}$ flowis just as accurate as the more complex 3D flow simulations, when predicting the frequency of a Type II SWJ with a nozzle depth to height ratio of $\mathrm{d} / \mathrm{h}=1$. We can conclude that the oscillation frequency in such geometric proportions and in the incompressible flow regimes does not depend on the $3 \mathrm{D}$ component of the internal flow.

We propose that this simple 2D URANS model is a good approximation to use in the future design and optimization of the SWJ actuator where the frequency is a fixed variable. Optimization of the SWJ design using, for example, genetic algorithms or genetic programming, is very effective, but requires many samples to be tested in the process. Such a large number of potential solutions could be easily supplied by a computationally inexpensive, yet sufficiently accurate CFD model, as proposed in this paper.

\section{ACKNOWLEDGMENTS}

This publication is based upon work supported by the Khalifa University of Science and Technology under Award No. FSU-2018-21 and KURIF-L1-1570230875. The authors would also like to thank the staff of the Fabrication Laboratory, especially J. Thomas and R. De Jesus for their exceptional support in this experiment.

\section{REFERENCES}

[1] Abbas, A., Vicente, J. and Valero, E.: Aerodynamic technologies to improve aircraft performance, Aerospace Science and Technology, vol. 28, pp. 100-132, 7, 2013.

[2] Monechi, B., Servedio, V., Loreto, V.: Congestion transition in air traffic networks, PLOS ONE, vol. 10, p. e0125546, 5, 2015.

[3] Gavrilović, N., Rašuo, B., Dulikravich, G., Parezanović, V.: Commercial aircraft performance improvement using winglets, FME Transactions, vol. 43, pp. 1-8, 2015.

[4] Katz, J.: Aerodynamics of race cars, Annual Review of Fluid Mechanics, vol. 38, pp. 27-63, 12006.

[5] Gad-el-Hak, M.: Flow control: passive, active, and reactive flow management, Cambridge University Press, 2007.

[6] Rašuo, B.: On Boundary Layer Control in TwoDimensional Transonic Wind Tunnel Testing, in IUTAM Symposium on One Hundred Years of Boundary Layer Research, Editors: Meier, G.E.A; Sreenivasan, K.R.; Heinemann, Hans-Joachim, Series: Solid Mechanics and Its Applications, Vol. 129, Springer Netherlands, 2006, pp. 473-482.

[7] Banjac, M., Nikolić, B.: Numerical study of smoke flow control in tunnel fires using ventilation systems, FME Transactions, vol. 36, pp. 145-150, 2008.

[8] De Lima, L., Vieira, R., Isoldi, L., Oliveira, R., Dos Santos, P., Dos Santos, D.: Numerical Analysis of a Turbulent Flow with Coanda Effect in Hydrodynamics Profiles, FME Transactions, vol. 45, no. 3, pp. 412-420, 2017.

[9] Bauer, M., Pannier, L.: Active jet noise reduction by oscillating mechanical flaps at the nozzle exit, in 18th AIAA/CEAS Aeroacoustics Conference (33rd AIAA Aeroacoustics Conference), 2012.

[10] Mirkov, N. and Rašuo, B.: Numerical simulation of air jet attachment to convex walls and application to UAV, in Boundary and Interior Layers, Computational and Asymptotic Methods - BAIL 2014, Editor: Knobloch, Petr, Series: Lecture Notes in Computational Science and Engineering, Vol. 108, Springer, pp. 197-207, 2015.

[11] Mirkov, N. and Rašuo, B.: Numerical Simulation of Air Jet Attachment to Convex Walls and Applications, 27th ICAS Congress, 19-24 September, Nice, France, Pages: 1-7 (CD-Rom), 2010.

[12] Mirkov, N., Rašuo, B.: Maneuverability of an UAV With Coanda Effect Based Lift Production, in 28th ICAS Congress, 23 - 28 September, Brisbane, Australia, Pages: 1-6 (CD-Rom), 2012.

[13]Zmijanović, V., Rašuo, B, Chpoun, A.: Flow separation modes and side phenomena in an overexpanded nozzle, FME Transactions, vol. 40, pp. 111$118,2012$.

[14]Živković, S., Milinović, M., Adamec, N.: Experimental and numerical research of a supersonic planar thrust vectoring nozzle via mechanical tabs, FME Transactions, vol. 42, pp. 205-211, 2014.

[15] Cattafesta, L., Sheplak, M.: Actuators for active flow control, Annual Review of Fluid Mechanics, vol. 43, pp. 247-272, 1, 2011.

[16] Raghu, S.: Fluidic oscillators for flow control, Experiments in Fluids, vol. 54, 1, 2013.

[17] Koklu, M.: Effect of a coanda extension on the performance of a sweeping-jet actuator, AIAA Journal, vol. 54, pp. 1131-1134, 3, 2016.

[18] Parezanović, V., Monchaux R. and Cadot, O.: Characterization of the turbulent bistable flow regime of a $2 \mathrm{~d}$ bluff body wake disturbed by a small control cylinder, Experiments in Fluids, vol. 56, no. $1,2015$.

[19] Phillips, E. and Wygnanski, I.: Use of sweeping jets during transient deployment of a control surface, AIAA Journal, vol. 51, pp. 819-828, 4, 2013.

[20] Bobusch, B., Woszidlo, R., Bergada, J., Nayeri, C. and internal flow structures inside a fluidic oscillator, Experiments in Fluids, vol. 54, 6, 2013.

[21] Woszidlo, R., Ostermann, F., Nayeri, C., Paschereit, C.: The time-resolved natural flow field of a fluidic oscillator, Experiments in Fluids, vol. 56, 6, 2015.

[22] Slupski, B., Kara, K.: Effects of feedback channels and coanda surfaces on the performance of sweeping jet actuator, in 55th AIAA Aerospace Sciences Meeting, 2017.

[23] Seo, J., Zhu, C., Mittal, R.: Flow physics and frequency scaling of sweeping jet fluidic oscillators, AIAA Journal, vol. 56, pp. 2208-2219, 6, 2018.

[24] Seifert, A. et al.: Oscillatory blowing: a tool to delay boundary-layer separation, AIAA Journal, vol. 31, pp. 2052-2060, 11, 1993.

[25] Woszidlo, R., Nawroth, H., Raghu, S., Wygnanski, I.: Parametric study of sweeping jet actuators for 
separation control, in 5th Flow Control Conference, 2010.

[26] Schmidt, H., Woszidlo, R., Nayeri, C., Paschereit, C.: Separation control with fluidic oscillators in water, Experiments in Fluids, vol. 58, 8, 2017.

[27] Kara, K.: Flow separation control using sweeping jet actuator, in 35th AIAA Applied Aerodynamics Conference, 2017.

[28] Slupski, B., Kara, K.: Separated flow control over naca 0012 airfoil using sweeping jet actuator, in 35th AIAA Applied Aerodynamics Conference, 2017.

[29] Guyot, D., Bobusch, B., Paschereit, C., Raghu, S.: Active combustion control using a fluidic oscillator for asymmetric fuel flow modulation, in 44th AIAA/ ASME/SAE/ASEE Joint Propulsion Conference Exhibit, 2008.

[30] Seele, R., Graff, E., Lin, J., Wygnanski, I.: Performance enhancement of a vertical tail model with sweeping jet actuators, in 51st AIAA Aerospace Sciences Meeting including the New Horizons Forum and Aerospace Exposition, 2013.

[31] Andino, M., Lin, J., Washburn, A., Whalen, E., Graff, E., Wygnanski, I.: Flow separation control on a full-scale vertical tail model using sweeping jet actuators, in 53rd AIAA Aerospace Sciences Meeting, 2015.

[32] Lin, J., Andino, M., Alexander, M., Whalen, E., Spoor, M., Tran, J., Wygnanski, I.: An overview of active flow control enhanced vertical tail technology development, in 54th AIAA Aerospace Sciences Meeting, 2016.

[33] Whalen, E., Lacy, D., Lin, J., Andino, M., Washburn, A., Graff, E., Wygnanski, I.: Performance enhancement of a full-scale vertical tail model equipped with active flow control, in 53rd AIAA Aerospace Sciences Meeting, 2015.

[34] Seele, R., Tewes, P., Woszidlo, R., McVeigh, M., Lucas, N., Wygnanski, I.: Discrete Sweeping Jets as Tools for Improving the Performance of the V22, Journal of Aircraft, vol. 46, pp. 2098-2106, 11, 2009.

[35] Seele, R., Graff, E., Gharib, M., Taubert, L., Lin, J. and Wygnanski, I.: Improving rudder effectiveness with sweeping jet actuators, in 6th AIAA Flow Control Conference, 2012.

[36] Ostermann, F., Godbersen, P., Woszidlo, R., Nayeri, C., Paschereit, C.: Sweeping jet from a fluidic oscillator in crossflow, Physical Review Fluids, vol. 2, 9, 2017.

[37] Koklu, M., Melton, L.: Sweeping jet actuator in a quiescent environment, in 43rd Fluid Dynamics Conference, 2013.

[38] Ostermann, F., Woszidlo, R., Nayeri, C., Paschereit, C.: Properties of a sweeping jet emitted from a fluidic oscillator, Journal of Fluid Mechanics, vol. 857, pp. 216-238, 10, 2018.

[39] Woszidlo, R. et al.: Fundamental properties of fluidic oscillators for flow control applications, AIAA Journal, vol. 57, pp. 978-992, 3, 2019.
[40] Vatsa, V., Koklu, M., Wygnanski, I.: Numerical simulation of fluidic actuators for flow control applications, in: 6th AIAA Flow Control Conference, 2012.

[41] Aram, S., Lee, Y., Shan, H. and Vargas, A.: Computational fluid dynamic analysis of fluidic actuator for active flow control applications, AIAA Journal, vol. 56, pp. 111-120, 1, 2018.

[42] Stouffer, R. andBower, R.: Fluidic flow meter with fiber optic sensor. U.S. Patent: 5,827,976, 1998.

[43] Kara, K.: Numerical study of internal flow structures in a sweeping jet actuator, in:33rd AIAA Applied Aerodynamics Conference, 2015.

[44] Slupski, B. and Kara, K.: Effects of Geometric Parameters on Performance of Sweeping Jet Actuator, in 34th AIAA Applied Aerodynamics Conference, 2016.

[45] Menter, F.: Two-equation eddy-viscosity turbulence models for engineering applications, AIAA Journal, vol. 32, pp. 1598-1605, 8, 1994.

[46] Von Gosen, F., Ostermann, F., Woszidlo, R., Nayeri, C., Paschereit, C.: Experimental investigation of compressibility effects in a fluidic oscillator, in $53 \mathrm{rd}$ AIAA Aerospace Sciences Meeting, 2015.

[47] Gokoglu, S., Kuczmarski, M., Culley, D. and Raghu, S.: Numerical studies of a fluidic diverter for flow control, in 39th AIAA Fluid Dynamics Conference, 2009.

[48] Hirsch, D. and Gharib, M.: Schlieren visualization and analysis of sweeping jet actuator dynamics, AIAA Journal, vol. 56, pp. 2947-2960, 8, 2018.

[49] Debien, A., Krbek, K., Mazellier, N., Duriez, T., Cordier, L., Noack, B., Abel, M. and Kourta, A.: Closed-loop separation control over a sharp edge ramp using genetic programming, Experiments in Fluids, vol. 57, 2, 2016.

[50] Parezanović, V., Cordier, L., Spohn, A., Duriez, T., Noack, B., Bonnet, J., Segond, M., Abel, M. and Brunton, S.: Frequency selection by feedback control in a turbulent shear flow, Journal of Fluid Mechanics, vol. 797, pp. 247-283, 5, 2016.

\section{О УТИЦАЈУ СКАЛИРАЊА ДИМЕНЗИЈА И ВАРИЈАЦИЈЕ МАСЕНОГ ПРОТОКА НА ФРЕКВЕНЦИЈУ АКТУАТОРА СА ОСЦИЛИРАЈУЋИМ МЛАЗОМ}

Бартош Ј. Слупски, Адбул Р. Таџик, Владимир Б. Парезановић, Куршат Кара

Овај рад презентује експерименталну и нумеричку студију фреквенција актуатора са осцилирајућим млазом, која је важан параметар при ефективној контроли граничног слоја. Мерења еволуције статичког притиска у реалном времену у повратним каналима актуатора су обављена уз помоћ високофреквентних сензора притиска. Осам нивоа масеног протока је испитано у експериментима (од 1 гр/сек до 8 гр/сек). Утицај скалирања актуатора је испитан 
на основној геометрији, као и на скалираним геометријама у размерама 2:1 и 1:2. Резултати откривају линеарне односе фреквенције осцилација и масеног протока, као и Струаловог и Маховог броја струјуња унутар актуатора. Експериментално добијени подаци су упоређени са резултатима нумеричких симулација, добијених помоћу комерцијалног пакета Ансис Флуент в17.2.
Резултати показују висок ниво подударности, између две методологије, иако је коришћен релативно једноставан и рачунски незахтеван дводимензиналнинумерички модел. Могућност тачне предикције фреквенција осцилације млаза, на бази једноставних нумеричких модела унутрашњег струјања, отвара врата даљим студијама оптимизације геометрије овог типа актуатора. 